\title{
Seismological and geological characterization of the crust in the southern part of northern Fossa Magna, central Japan
}

\author{
Hiroshi Sato ${ }^{1}$, Takaya Iwasaki ${ }^{1}$, Yasutaka Ikeda ${ }^{2}$, Tetsuya Takeda ${ }^{1}$, Nobuhisa Matsuta ${ }^{1}$, \\ Tomoko Imai $^{1}$, Eiji Kurashimo ${ }^{1}$, Naoshi Hirata ${ }^{1}$, Sin'ichi Sakai ${ }^{1}$, Driss Elouai ${ }^{3}$, \\ Taku Kawanaka ${ }^{4}$, Shinji Kawasaki ${ }^{4}$, Susumu Abe ${ }^{4}$, Takeshi Kozawa ${ }^{4}$, \\ Takeshi Ikawa ${ }^{4}$, Yoshimasa Arai $^{5}$, and Naoko Kato ${ }^{1}$ \\ ${ }^{1}$ Earthquake Research Institute, University of Tokyo, 1-1-1 Yayoi, Tokyo 113-0032, Japan \\ ${ }^{2}$ Department of Earth and Planetary Science, 7-3-1 Hongo, University of Tokyo, Tokyo 113-0033, Japan \\ ${ }^{3}$ Department of Earth and Planetary Systems Science, Hiroshima University, \\ 1-3-1 Kagamiyama, Higashi-Hiroshima 739-8526, Japan \\ ${ }^{4}$ JGI Inc., 1-5-21, Otsuka, Tokyo 112-0012, Japan \\ ${ }^{5}$ Tokyo Electric Power Company, 212-1 Katsuyama, Ueno, Gunma 370-1613, Japan
}

(Received May 31, 2004; Revised December 27, 2004; Accepted December 27, 2004)

\begin{abstract}
The northern Fossa Magna (NMF) is a Miocene rift basin formed in the final stages of the opening of the Sea of Japan. The northern part of Itoigawa-Shizuoka Tectonic Line (ISTL) bounds the western part of the NMF and forms an active fault system that displays one of the largest slip rates in the Japanese islands. Reflection and refraction/wide-angle reflection profiling and earthquake observations by a dense array were undertaken across the northern part of ISTL in order to delineate structures in the crust, and deep geometry of the active fault systems. The ISTL active fault system at depth (ca. $2 \mathrm{~km}$ ) shows east-dipping low-angle in Omachi and Matsumoto and is extended beneath the Central Uplift Zone and Komoro basin keeping the same dip-angle down to ca. $15 \mathrm{~km}$. The upper part of the crust beneath the Central Uplift Zone is marked by the high Vp and high resistivity zone. Beneath the folded zone of the NMF, the middle to lower crust shows low Vp, low resistivity and more reflective features. The balanced geologic cross-section based on the reflection profiles suggests that the shortening deformation since the late Neogene was produced by the basin inversion of the Miocene low-angle normal fault.
\end{abstract}

Key words: Crustal structure, geologic structure, active fault, Itoigawa-Shizuoka tectonic line, northern Fossa Magna, seismic reflection profile, seismic refraction profile, central Japan.

\section{Introduction}

To construct a realistic model to explain crutal deformation processes in the short term $(<100$ years $)$ to long term is important for a better understanding of the occurrence of crustal devastative earthquakes and seismic hazards. Geodetic measurements, including triangulation for nearly 100 years and GPS measurements, suggest that strain accumulation has occurred around the northern part of the Itoigawa-Shizuoka tectonic Line (ISTL) active fault system and northern Fossa Magna, central Japan (Fig. 1; Sagiya et al., 2002). Also, on the evidence of paleo-seismology (Okumura, 2001), the ISTL active fault system poses the highest seismic risk and shows one of the largest slip rates (4-9 mm/yr) among active onshore faults (e.g. Ikeda et al., 2002). Based on such features, the northern part of the ISTL active fault system provides an excellent opportunity to reveal on-going crustal deformation mechanisms and processes, and was determined as a target area for the research project on "Slip and Flow Processes in and below the Seismogenic Region”.

Copy right(c) The Society of Geomagnetism and Earth, Planetary and Space Sciences (SGEPSS); The Seismological Society of Japan; The Volcanological Society of Japan; The Geodetic Society of Japan; The Japanese Society for Planetary Sciences; TERRAPUB.
Revealing the crustal architecture of the target area is an important key to construct the numerical model for crustal deformation. For this purpose, multi-disciplinary research to reveal the crustal structure has been carried out, including seismic reflection profiling (Sato et al., 2004a), seismic refraction/wide-angle reflection profiling (Imai et al., 2004; Takeda et al., 2004), seismic tomography (Kurashimo and Hirata, 2004), receiver function analysis (Yoshimoto et al., 2004; Abe et al., 2004), and resistivity structure by magnetotelluric (MT) method (Ogawa et al., 2002) across the northern part of the ISTL active fault system. In this paper, we try to synthesize the crustal structure of the northern Fossa Magna region and deep geometry of the ISTL active fault system based on the above-mentioned results and other related seismic profiles (Matsuta et al., 2004; Ikeda et al., 2004; Elouai et al., 2004).

\section{Geological Setting}

The northern part of the ISTL is defined as the western boundary fault of the Neogene sedimentary basin, named Fossa Magna. The tectonic line, which separates the preTertiary basement of the NE Japan from SW Japan, is the Tanakura Shear Zone (e.g. Otsuki, 1975; Fig. 1). The ISTL produced a certain displacement in pre-Tertiary basement, 

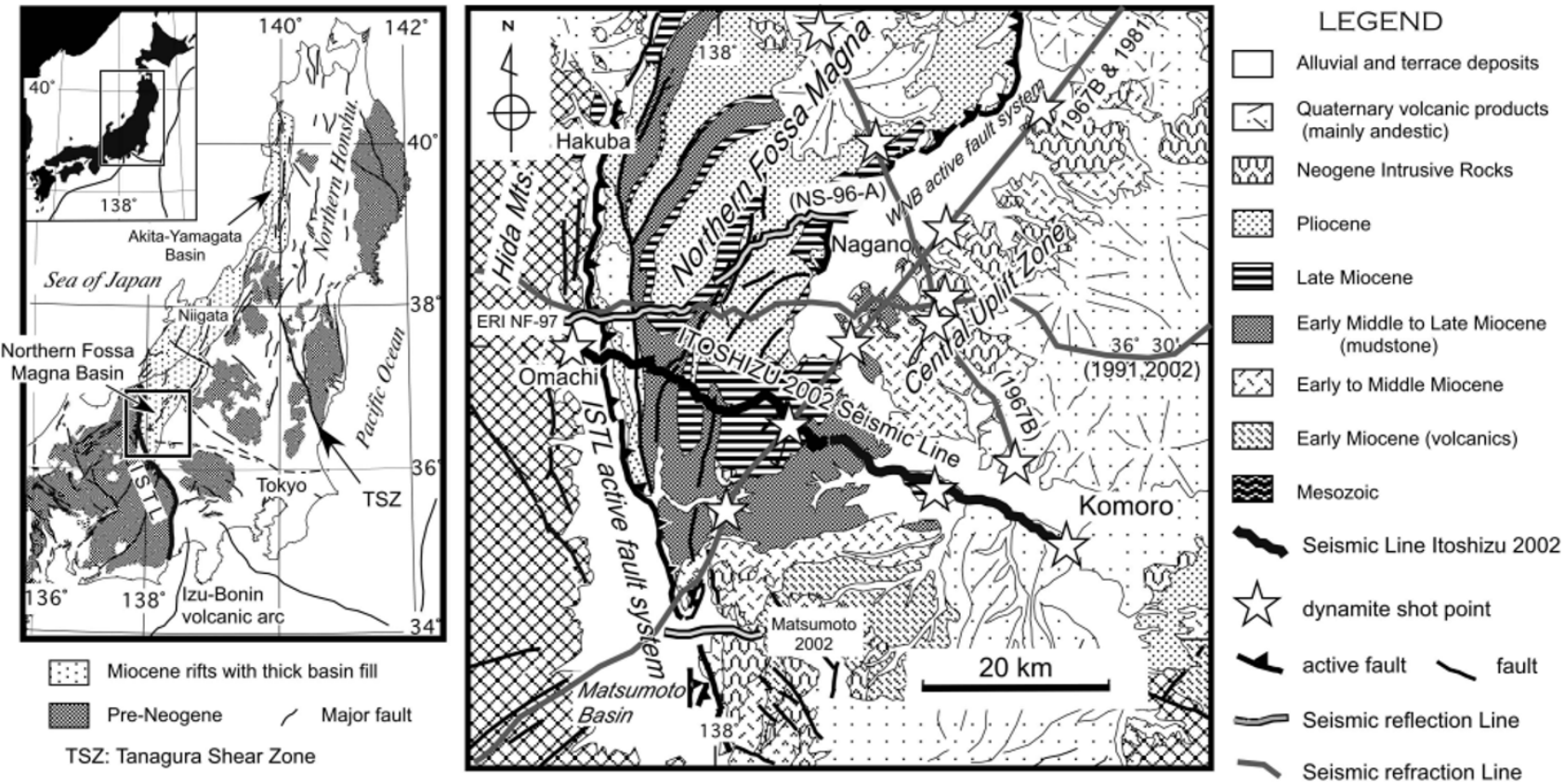

Fig. 1. Geologic map of the northern Fossa Magna (Geological Survey of Japan, 1992) and location of seismic lines.

which belongs to the geologic belts in SW Japan. However, due to a thick Neogene sedimentary cover, the tectonic movement of ISTL in Pre-Neogene is poorly understood. Judging from the basin fill, the formation of the northern part of the ISTL and northern Fossa Magna is closely related to the formation of the Sea of Japan and northern Honshu rift system (Sato et al., 2004a). In the southern Fossa Magna region, the fore-arc sediments of Honshu arc and the sediments deposited on the Izu-Bonin arc are strongly deformed by the collision of the two arcs. The southern ISTL was produced by this collision processes (Kano et al., 1990) and its nature and geometry is very different from the northern one. The northern part of the ISTL has an east-dipping fault plane, yet the southern part shows a west-dipping fault plane. Therefore, the ISTL should not be considered as a single fault system, it consists of two fault systems different in origin and deep geometry.

The northern Fossa Magna was formed as a rift basin located in the southern end of the northern Honshu rift system. In the northern part of the basin, more than 6 $\mathrm{km}$ of marine sediments have accumulated (Kato, 1992). The Neogene basin fill is strongly folded with NE trending axial trace (Fig. 1). The Central Uplift Zone trends parallel to the northern Fossa Magna basin and consists of gently dipping lower Miocene submarine mudstone and volcanic rocks. A negative Bouguer gravity anomaly zone $25 \mathrm{~km}$ in width is formed east of, and parallel to, the Central Uplift Zone (Hiroshima et al., 1994). However, due to the cover of Quaternary volcanic products, the age of the infill of this basin is uncertain.

The central part of the ISTL forms active fault systems with high slip-rate of 4-9 mm/y (Matsuta et al., 2004; Ikeda et al., 2004). However, the northernmost part of ISTL, north of Hakuba, shows no evidence of late Quaternary faulting (Togo et al., 1996). In other words, along the northernmost part of ISTL, there is no evidence suggesting that this fault is a plate boundary between Eurasia and North American plates (e.g. Nakamura, 1983) at least since late Quaternary.

\section{Velocity Structure Obtained from Refraction/ Wide-Angle Reflection Profiling}

Since the 1960's, several seismic experiments have been carried out in the northern Fossa Magna region, including Asano et al. (1969), Ikami et al. (1986), Sakai et al. (1996) and Takeda (1997). The previous data were reprocessed by Takeda et al. (2004). In this project, the seismic reflection (Sato et al., 2004a), refraction/wide-angle reflection (Imai et al., 2004) data were acquired across the ISTL active fault system with a 68-km-long seismic line (Itoshizu 2002; Fig. 1). The obtained P-wave velocity model by Imai et al. (2004) using a 2-D ray tracing method (Iwasaki, 1988) is shown in Fig. 2. The most prominent feature is the "Central Uplift Zone", flanked on the west and east by sedimentary basins. Low velocity layers below the ISTL active fault, extend beneath the Central Uplift Zone, showing a thin wedge-shaped geometry. The upper interface of the low velocity zone is interpreted as the deeper extension of the ISTL active fault at least just beneath the Central Uplift Zone. The connectivity of the probable deeper extension of the ISTL active fault and the thin low velocity layer beneath the eastern flank of the Central Uplift Zone is obscure.

The main geologic structure such as the northern Fossa Magna basin, Central Uplift Zone and the Komoro basin is clearly indicated by several seismic lines in northern Fossa Magna area (Takeda et al., 2004). The depth of the base of Neogene basin fill in the northern Fossa Magna increases to the northeastward.

\section{Fault Geometry Based on the Seismic Reflec- tion Profiles}

The common mid-point (CMP) seismic reflection profiling was carried out at several seismic lines across the ISTL 

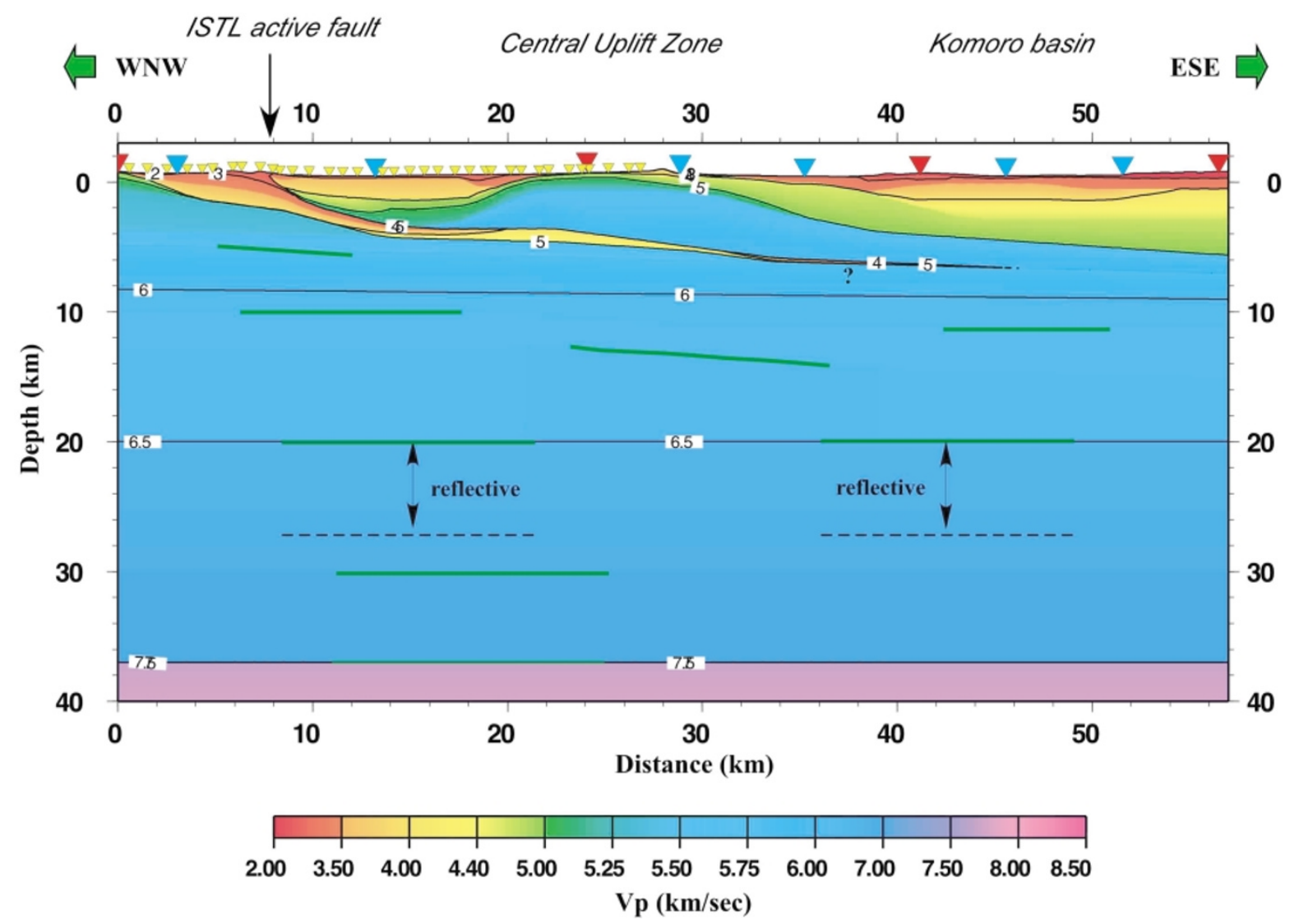

Fig. 2. P-wave velocity structure by ray-tracing method along Itoshizu 2002 seismic line (Sato et al., 2004a) after Imai et al. (2004). Red triangles: locations of explosive sources, blue triangles: locations of high energy shots (a large number of sweeps) by vibroseis trucks, yellow triangles: locations of vibroseis shot points used in this analysis. Green lines represent the reflectors clearly observed on the shot gathers by explosive sources.

active fault system. The representative line is the Itoshizu 2002 (Sato et al., 2004a; Fig. 1). Seismic data were acquired using four vibroseis trucks and explosive sources. Resultant depth converted seismic sections and its geologic interpretation are shown in Fig. 3. The obtained seismic profiles, including a shallow high-resolution profile along the same seismic line (Matsuta et al., 2004), suggest that the ISTL active fault forms an emergent thrust with a dipangle of 30 degrees to the east at the shallow depth $(<2$ $\mathrm{km})$. The deeper extension of this fault can be traced in the Miocene basin fill with low-angle and possibly traced beneath the Central Uplifted Zone (Sato et al., 2004a; Fig. 3 suggested by arrows Y). The boundary between Cretaceous granitic rocks and Neogene sediments is clearly recognized by strong continuous reflections and can be traced down to $3 \mathrm{~km}$ at a distance of $6 \mathrm{~km}$ from the western end (Fig. 3, $\mathrm{X})$. The boundary between the Cretaceous and Neogene and the extension of the ISTL active fault are estimated to merge beneath the Central Uplift Zone. Based on our velocity model and seismic reflection profile and available geologic data (e.g. Kato, 1980; Kato and Sato, 1983; Kato and Akabane, 1986; Kato et al., 1989; Arai, 2000), the seismic section of Itoshizu 2002 is interpreted as shown in Fig. 3. The low-angle fault geometry of the ISTL active fault system at the depth more than $2-\mathrm{km}$ is also demonstrated by seismic reflection profile in Matsumoto (Matsumoto 2002 in Fig. 1; Ikeda et al., 2004). This geometry well accords to the velocity structure obtained by the reprocessing of re- fraction data of the 1987 seismic line (Fig. 1, Takeda et al., 2004). The similar geometry of the ISTL active fault system is also presented in ERI NF 97 seismic line, located north of the Itoshizu 2002 seismic line (Fig. 1; Elouai et al., 2004).

\section{Relationship between Velocity Structure, Fault Geometry and Other Geophysical Features}

Along the Itoshizu 2002 seismic lines, earthquakes were recorded for two months by a dense array of temporary seismic stations. Based on these data, the crustal structure was investigated by seismic tomography (Kurashimo and Hirata, 2004) and receiver function analysis (Abe et al., 2004). Resistivity structure along the same profile was also obtained by the magnetotelluric method (Ogawa et al., 2002).

According to the receiver function analysis using $\mathrm{CCP}$ (common-conversion-point) stacking and prestack migration of teleseismic P-SV converted wave, two P-S converted interfaces are identified at a depth of $17-18 \mathrm{~km}$ and $38-40$ $\mathrm{km}$. The later phase with positive polarity can be interpreted as the P-S conversion from the Moho (Abe et al., 2004). Figure 4 is a shot record of the explosive source at the western end of the Itoshizu 2002 seismic line. The coherent reflections can be recognized from 6 to $13 \mathrm{sec}$ (TWT: twoway travel time), suggesting that the laminated lower crust extends up to $13 \mathrm{sec}$ (TWT). From these observations, it is highly probable that the Moho-depth is located at about 40 $\mathrm{km}$. 

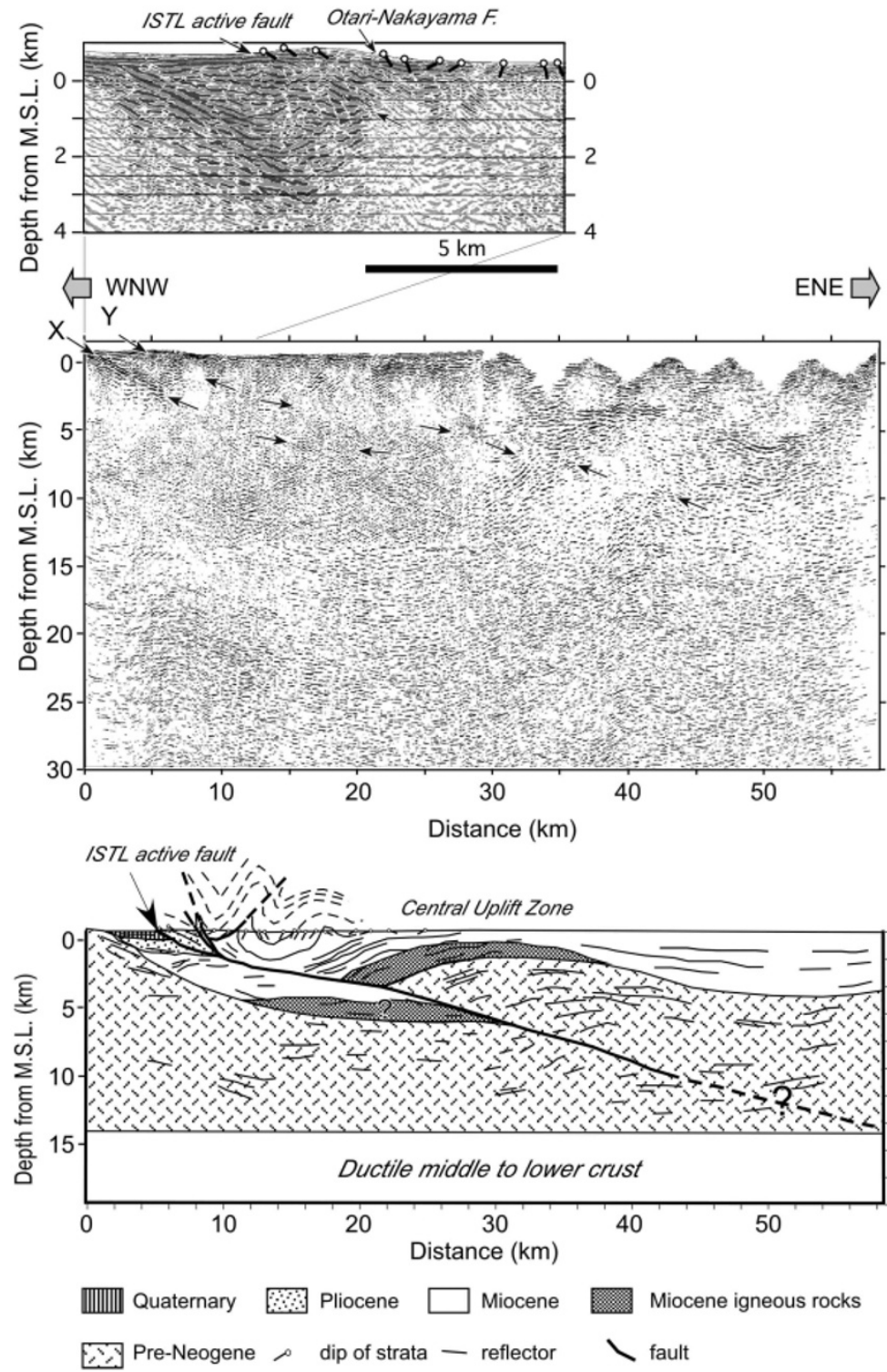

Fig. 3. Stacked, migrated, depth converted seismic sections of Itoshizu 2002 and its geologic interpretation after Sato et al. (2004a). X: base of Neogene, Y: deeper extension of the ISTL active fault.

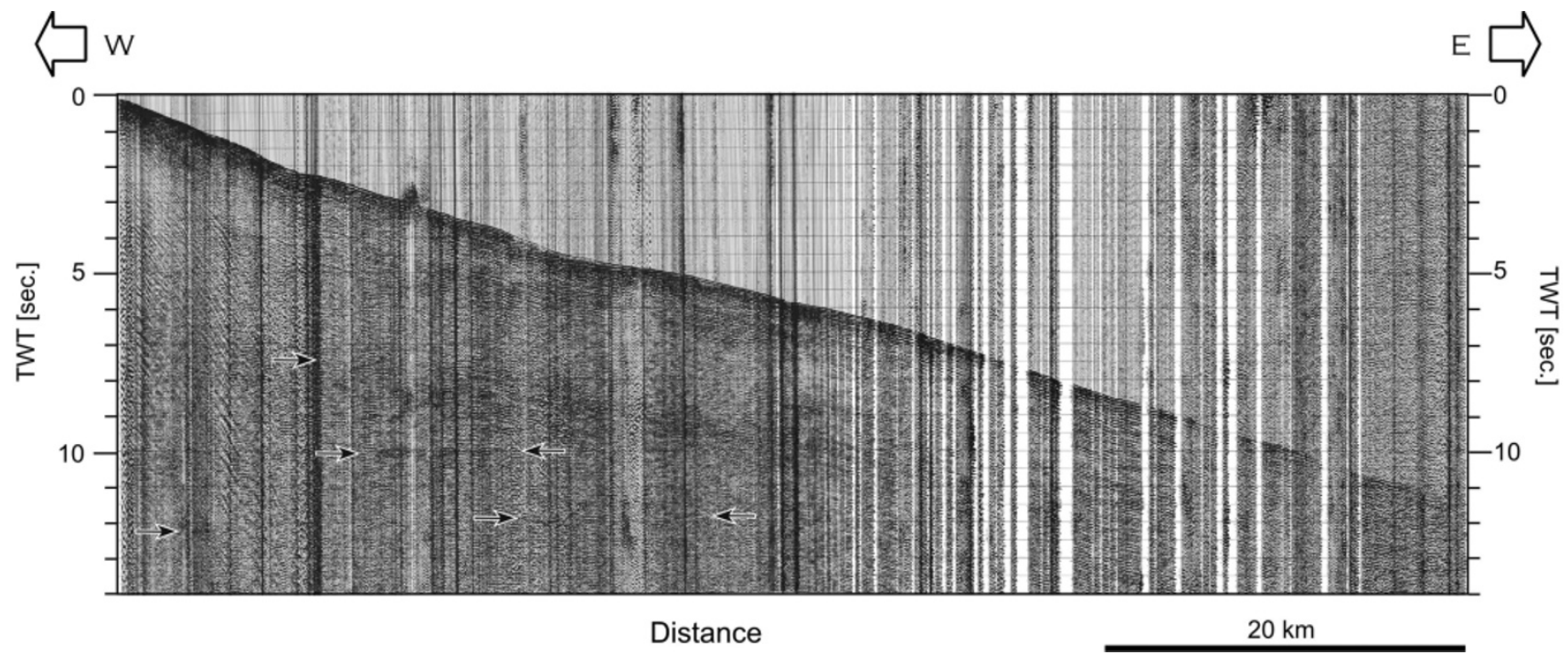

Fig. 4. Shot record by explosive source (100 kg of dynamite) at the western end of the Itoshizu 2002 seismic line. Arrows indicate the significant reflection from middle to lower crust. 


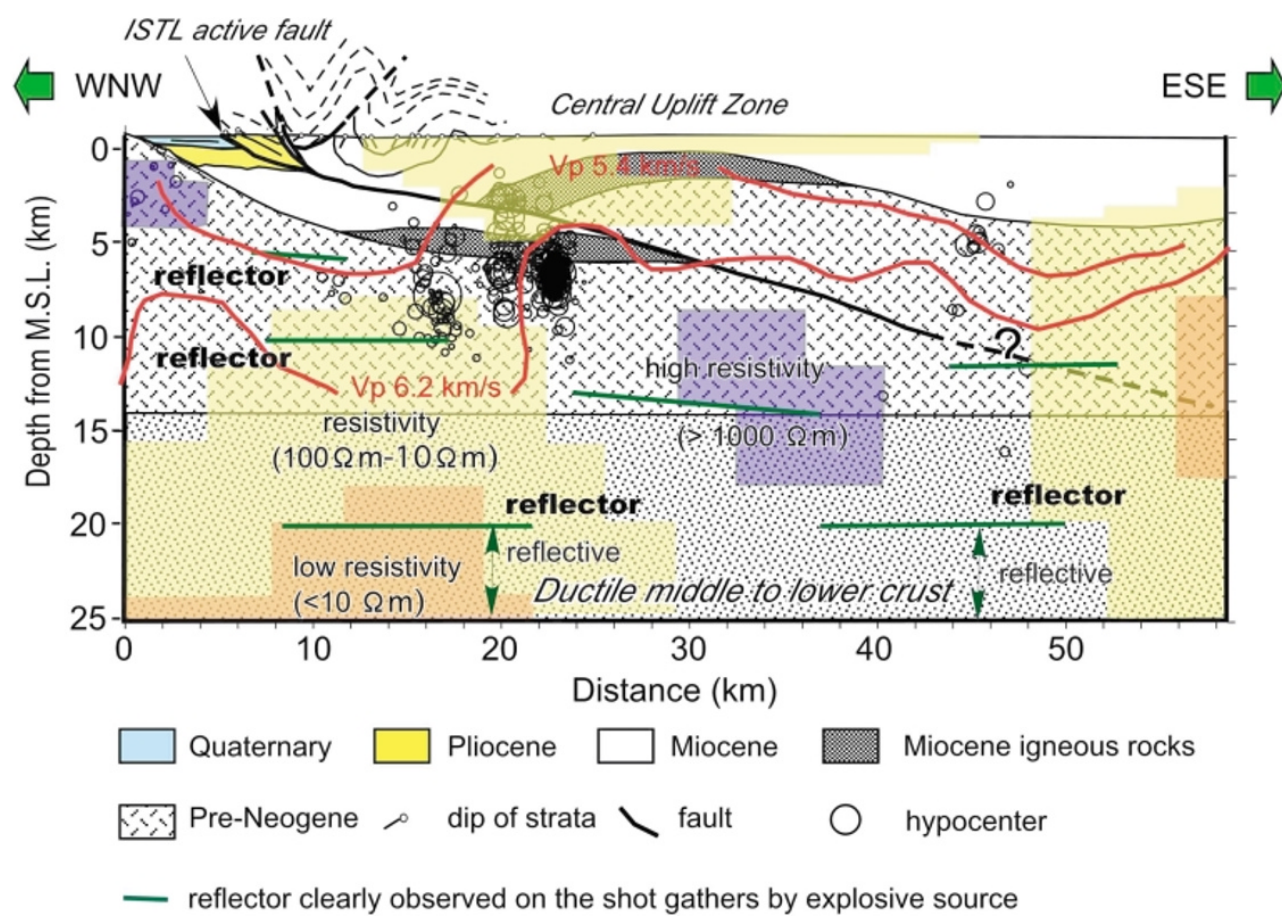

Fig. 5. Geologic cross-section along the Itoshizu 2002 seismic line (Sato et al., 2004a) with the resistivity structure (Ogawa et al., 2002), the hypocentral distribution (Sakai, 2004) and P-wave velocity structure obtained by seismic tomography (Kurashimo and Hirata, 2004). The location of deep reflectors is after Imai et al. (2004).

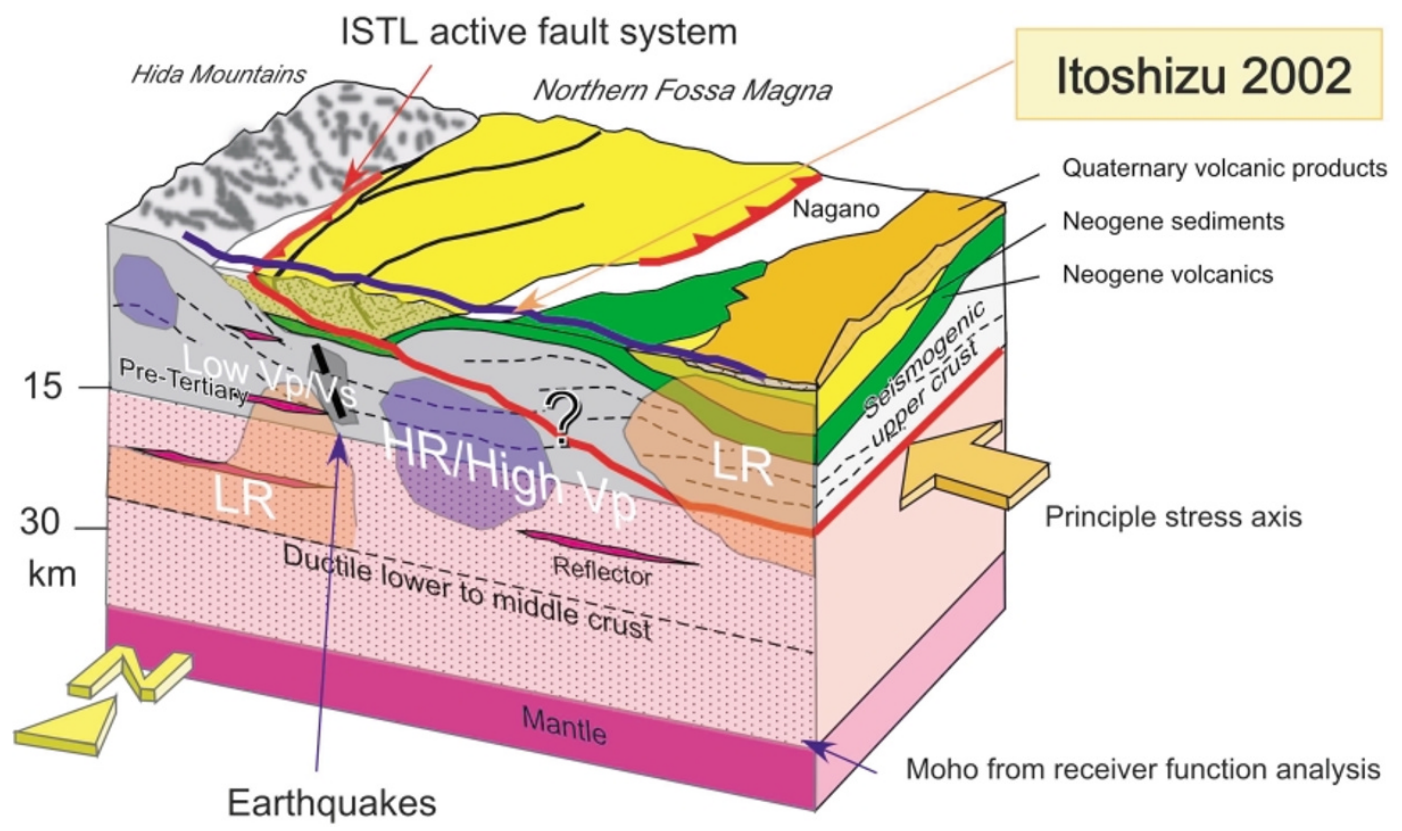

Fig. 6. Schematic illustration showing the crustal structure around the southern part of the northern Fossa Magna.

The resistivity structure along the Itoshizu 2002 (Ogawa et al., 2002), the relocated, hypocentral distribution (Sakai, 2004) and the reflectors observed on the shot gathers by explosive sources (Imai et al., 2004) are superposed on the geologic cross-section (Fig. 5). The high resistivity area beneath the Central Uplift Zone $(\sim 20 \mathrm{~km})$ is almost coincidence with the high velocity area obtained by seismic tomography analysis (Kurashimo and Hirata, 2004). The basement beneath the folded zone of the northern Fossa Magna basin is marked by the low resistivity (Ogawa et al., 2002), low Vp (Kurashimo and Hirata, 2004; Takeda et al., 2004), low to moderate Vp/Vs (Kurashimo and Hirata, 2004) and distribution of the clear reflectors (e.g. Fig. 3). Kurashimo and Hirata (2004) suggested the existence of aqueous fluid pores with high aspect rations in this zone.

Using the obtained velocity structure by refraction analysis, hypocentral distribution of micro-earthquakes were redetermined and projected on the Itoshizu 2002 seismic line (Sakai, 2004; Fig. 5). Most of micro-earthquakes occur in the footwall of the ISTL active fault system. As suggested 


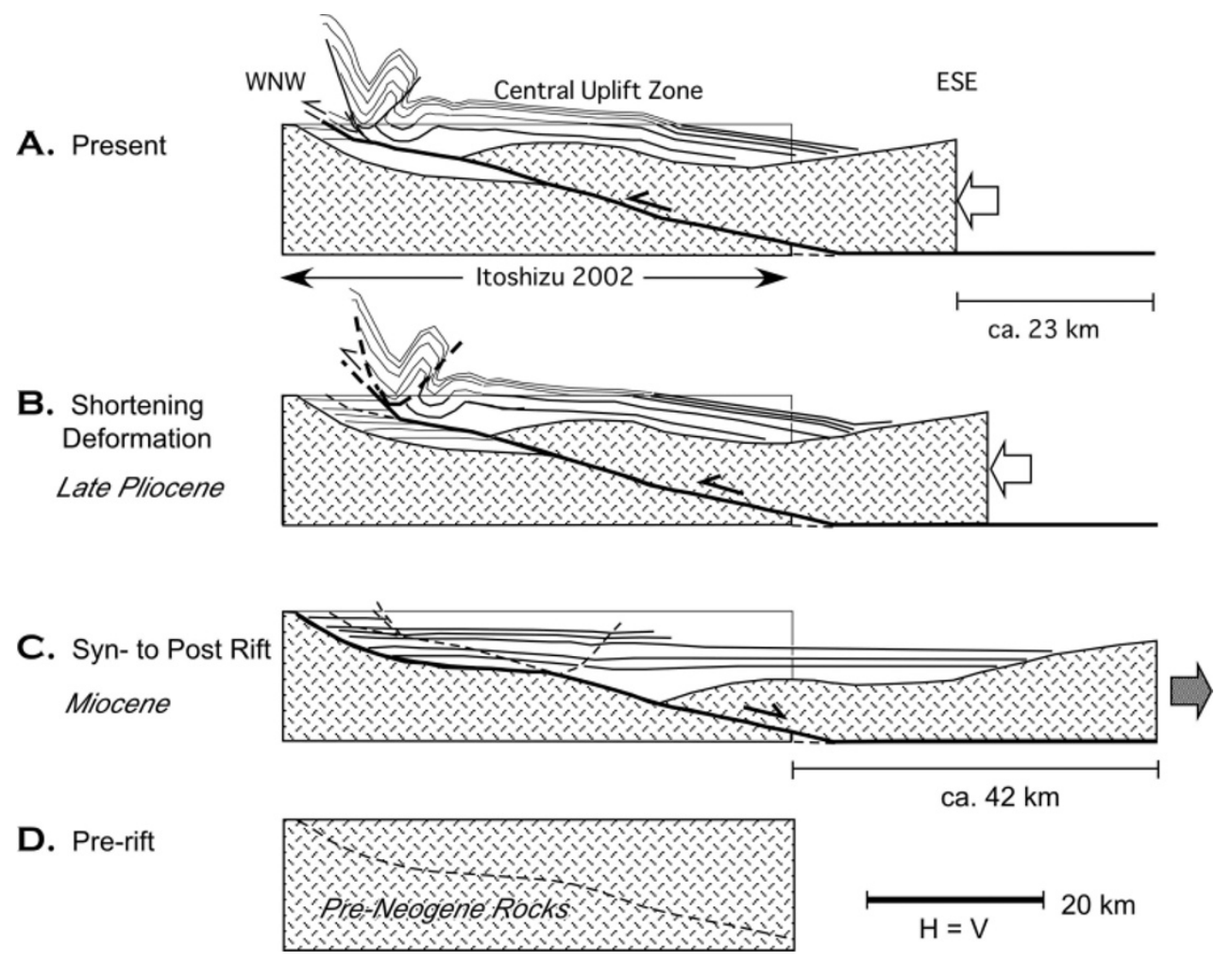

Fig. 7. Schematic diagram showing the evolution of the northern Fossa Magna after Sato et al. (2004a).

by Ogawa et al. (2002), the hypocentral distribution has tendency to concentrate between low and high resistivity area. The focal mechanisms of these earthquakes are strike-slip with WNW trending P-axis (Sakai, 2004). Including the northern Fossa Magna region, the most of the focal mechanisms in the back-arc side of the southern part of the northern Honshu shows the strike-slip type with WNW trending P-axis (Kosuga, 1999). However, active faults distributed in this region are dominated in reverse faults. This incompatibility suggests that the stress condition which generates large earthquakes associated with faulting along the pre-existing active-seismogenic source fault probably differ from the one of micro-earthquakes in steady state and/or stress build up processes.

The observed micro-earthquakes in the footwall, forming the NNW trending zone (Sakai, 2004), are possibly produced by slip of preexisting NNW trending fault system and/or triggered by migration of fluid to less permeable (more resistive) crust (e.g. Ogawa et al., 2001). However, we cannot find evidence showing the large vertical displacement along the estimated high-angle fault beneath the surface trace of the ISTL (Imai et al., 2004). It is reasonable to release the strike-slip components by slip on such highangle fault. However, it seems to be very difficult to release the significant amount of WNW- trending strain by NNW-trending high-angle fault. Thus, we interpreted that the deeper extension of the ISTL active fault does not connect to this high angle-fault (Fig. 6).

\section{Tectonic Model for the Evolution of Northern Fossa Magna Basin}

The basin formation and subsequent inversion processes in the northern Fossa Magna basin can be explained using a simple model based on fault reactivation along the ISTL (Sato and Ikeda, 1999a; Sato et al., 2004a; Fig. 7). In this reconstruction ca. $42 \mathrm{~km}$ of Miocene extension is estimated (Fig. 7, C and D). The total amount of shortening since the late Neogene is estimated to be ca. $23 \mathrm{~km}$. If the shortening started at 6-4 Ma, the averaged slip rate is calculated as 4-6 mm/y under a constant slip rate. This value is similar to the rate obtained by drilling and very shallow seismic reflection profiling across the toe of the thrust in northern part of the ISTL active fault system from the late Quaternary (4.7 mm/y; Matsuta et al., 2001).

In the northernmost part of the ISTL, the faulting has terminated since late Quaternary. In the northern part of northern Fossa Magna, the late Quaternary horizontal shortening accommodated along the western Nagano basin active fault system (Fig. 1). The shift of the location of late Quaternary faulting from the western end (ISTL active fault system) to the eastern end of the Northern Fossa Magna basin (western Nagano basin active fault system) is easily understood as the shortening deformation processes of the basin fill caused by the thrusting of the east-dipping master fault beneath the Central Uplift Zone (Elouai et al., 2004; Takeda et al., 2004).

\section{Conclusions}

The northern part of ISTL was formed as a low-angle normal fault in Miocene, bounding the western margin of the northern Fossa Magna rift basin. Due to the shortening de- 
formation since late Neogene, the present ISTL active fault system was developed in the basin fill by basin inversion processes.

Low $\mathrm{Vp}$, low $\mathrm{Vp} / \mathrm{Vs}$ and low resistivity are observed beneath the folded zone of the northern Fossa Magna. Such crustal structure has potential to give significant amounts of control for seismicity and crustal deformation processes.

Acknowledgments. We are grateful to the members of research project on "Slip and Flow Processes in and below the Seismogenic Region" for helpful discussions and comments. We also thank Tim Stern, Yasuo Ogawa and an anonymous refree for critical reviews. The seismic experiment of Itoshizu 2002 and the related research were supported by the above-mentioned project and Grant-in-Aid for Scientific Research No. 14209004 provided from the Ministry of Education, Culture, Sports, Science and Technology, Japan.

\section{References}

Abe, S., E. Kurashimo, H. Sato, N. Hirata, and T. Kawanaka, Seismic migration of receiver functions for deep crustal structure across the Itoigawa-Shizuoka tectonic line with dense broad-band seismic arrays, Proceedings of the 2nd International Symposium on Slip and Flow Process in and below the Seismogenic Region, Tokyo, Japan, 2004.

Arai, Y., The late Cenozoic tectonics of the northern Fossa Magna, Master thesis, Graduate School of Science, The Univ. of Tokyo, Tokyo, 182 pp., 2000.

Asano, S., K. Ichikawa, H. Okada, S. Kubota, H. Suzuki, M. Nogoshi, H. Watanabe, K. Seya, K. Noritomi, and K. Tazime, Explosion seismic observations in the Matsushiro Earthquake Swarm Area, Spec. Rep. Geol. Survey of Japan, 5, Part I, 1-162, 1969.

Elouai, D., H. Sato, N. Hirata, S. Kawasaki, T. Takeshita, N. Kato, and T. Takeda, Deep seismic reflection profiling across the northern Fossa Magna: The ERI 1997 and the JNOC 1996 seismic lines, active faults and geological structures, Earth Planets Space, 56, this issue, 13331340, 2004.

Geological Survey of Japan (eds.), 1:1,000,000 Geological Map of Japan (3rd ed.), Geological Survey Japan, Tsukuba, 1992.

Hiroshima, T., M. Komazawa, and T. Nakatsuka, Gravity Map of Joshinetsu District (Bouguer Anormalies) 1:200000, Geological Survey of Japan, 1994.

Ikami, A., T. Yoshii, S. Kubota, Y. Sasaki, A. Hasemi, T. Moriya, H. Miyamachi, R. Matsu'ura, and K. Wada, A seismic refraction profile in and around Nagano Prefecture, Central Japan, J. Phys. Earth, 34, 457-474, 1986.

Ikeda, Y., T. Imaizumi, M. Togo, K. Hirakawa, T. Miyauchi, and H. Sato (eds.), Atlas of Quaternary Thrust Faults in Japan, Univ. of Tokyo Press, Tokyo, 254 pp., 2002 (in Japanese).

Ikeda, Y., T. Iwasaki, H. Sato, N. Matsuta, and T. Kozawa, Seismic reflection profiling across the Itoigawa-Shizuoka Tectonic Line at Matsumoto, Central Japan, Earth Planets Space, 56, this issue, 1317-1323, 2004.

Imai, T., T. Iwasaki, T. Takeda, T. Kawanaka, and H. Sato, Detailed upper crustal structure across the Itoigawa-Shizuoka Tectonic Line from the 2002 seismic expedition, Abstracts 2004 Japan Earth and Planetary Science Joint Meeting, S075-005, 2004.

Iwasaki, T., Ray-tracing program for study of velocity structure by ocean bottom seismographic profiling, Zisin (J. Seismol. Soc. Japan), 41, 263266, 1988 (in Japanese).

Kano, K., K. Kosaka, M. Murata, and S. Yanai, Intra-arc deformation with the vertical rotation axes: The case of the pre-Middle Miocene terranes of Southwest Japan, Tectonophysics, 176, 333-354, 1990.

Kato, H., Geology of the Sakaki District, Quardrangle Series, Scale 1:50000, Geol. Surv. Japan, 57 pp., 1980 (in Japanese with English Abstract).

Kato, H., Fossa Magna-A masked border region separating southwest and northeast Japan, Bull. Geol. Surv. Japan, 43, 1-30, 1992.

Kato, H. and S. Akabane, Geology of the Nagano District. Quardrangle Series, Scale 1:50000, Geol. Surv. Japan, 122 pp., 1986 (in Japanese with English Abstract).

Kato, H. and T. Sato, Geology of the Shinanoikeda District. Quardrangle Series, Scale 1:50000, Geol. Surv. Japan, 93 pp., 1983 (in Japanese with
English Abstract).

Kato, H., K. Mimura, T. Sato, and F. Takizawa, Geology of the Omachi District Quardrangle Series, Scale 1:50000, Geol. Surv. Japan, 111 pp., 1989 (in Japanese with English Abstract).

Kosuga, M., Stress regime of the NE Japan deduced from crustal earthquakes, Earth Monthly, 27, 107-112, 1999 (in Japanese).

Kurashimo, E. and N. Hirata, Low $V p$ and $V p / V s$ zone beneath the northern Fossa Magna basin, central Japan, derived from a dense array observation, Earth Planets Space, 56, this issue, 1303-1310, 2004.

Matsuta, N., Y. Ikeda, T. Imaizumi, and H. Sato, Subsurface structure of and rate of net slip on the Kamishiro fault, northern part of the ItoigawaShizuoka Tectonic Line, central Japan, Active Fault Research, 20, 5970, 2001 (in Japanese with English Abstract).

Matsuta, N., Y. Ikeda, and H. Sato, The slip rate along the northern Itoigawa-Shizuoka tectonic line active fault system, central Japan, Earth Planets Space, 56, this issue, 1325-1332, 2004.

Nakamura, K., Possibility of a nascent plate boundary at the eastern margin of the Japan Sea, Bull. Earthquake Res. Inst., Univ. Tokyo, 58, 711-722, 1983 (in Japanese).

Ogawa, Y., M. Mishina, T. Goto, H. Satoh, N. Oshiman, T. Kasaya, Y. Takahashi, T. Nisitani, S. Sakanaka, M. Uyeshima, Y. Takahashi, Y. Honkura, and M. Matsushima, Magnetotelluric imaging of fluidsin intraplate earthquakes zones, NE Japan back arc, Geophysical Research Letters, 28, 3741-3744, 2001.

Ogawa, Y., S. Takakura, and Y. Honkura, Resistivity structure across Itoigawa-Shizuoka tectonic line and its implications for concentrated deformation, Earth Planets Space, 54, 1115-1120, 2002.

Okumura, K., Paleoseismology of the Itoigawa-Shizuoka tectonic line in central Japan, Jour. Seismol., 5, 411-431, 2001.

Otsuki, K., Geology of the Tanakura Sear Zone and adjacent area, Contrib. Inst. Geol. Paleontol. Tohoku Univ., 76, 1-75, 1975 (Japanese with English abstract).

Sagiya, T., T. Nishimura, Y. Iio, and T. Tada, Crustal deformation around the northern and central Itoigawa-Shizuoka Tectonic Line, Earth Planets Space, 54, 1059-1063, 2002.

Sakai, S., Seismicity of the northern part of Itoigawa-Shizuoka Tectonic Line, Proceedings of the 2nd International Symposium on Slip and Flow Process in and below the Seismogenic Region, Tokyo, Japan, 2004.

Sakai, S., T. Iwasaki, T. Iidaka, T. Yoshii, F. Yamazaki, and T. Kuwayama, The structure of the crust of Chubu region from the explosion observation, Earth Monthly, 18, 104-108, 1996 (in Japanese).

Sato, H. and Y. Ikeda, Major fault systems in northern Honshu, Japan, Earth Monthly, 21, 569-575, 1999 (in Japanese).

Sato, H., T. Iwasaki, S. Kawasaki, Y. Ikeda, N. Matsuta, T. Takeda, N. Hirata, and T. Kawanaka, Formation and shortening deformation of a back-arc rift basin revealed by deep seismic profiling, central Japan, Tectonophysics, 388, 47-58, 2004a.

Sato, H., T. Yoshida, T. Iwasaki, T. Sato, Y. Ikeda, and N. Umino, Late Cenozoic tectonic development of the back arc region of central northern Honshu, Japan, revealed by recent deep seismic profiling, J. Jpn. Assoc. Petrol. Tech., 69, 145-154, 2004b (in Japanese with English abstract).

Takeda, T., Detailed crustul structure in central Japan as revealed from reanalysis of wide-angle data, Master thesis, Graduate School of Science, The Univ. of Tokyo, 26 pp., 1997 (in Japanese).

Takeda, T., H. Sato, T. Iwasaki, N. Matsuta, S. Sakai, T. Iidaka, and A. Kato, Crustal structure in the northern Fossa Magna region, central Japan, modeled from refraction/wide-angle reflection data, Earth Planets Space, 56, this issue, 1295-1301, 2004.

Togo, M., Y. Ikeda, T. Imaizumi, and H. Sato, Fault morphology of both ends of the Kamishiro fault along the Itoigawa-Shizuoka Tectonic Line, central Japan, Active Fault Res., 15, 9-16, 1996 (in Japanese with English abstract).

Yoshimoto, K., H. Fujisawa, T. Okada, N. Umino, A. Hasegawa, K. Obara, K. Shiomi, H. Tsukahara, S. Okamoto, T. Kawanaka, Hiroshi Sato, T. Nishimura, Haruo Sato, and M. Ohtake, Moho and Philippine Sea plate structure beneath central Honshu island, Japan, from teleseismic receiver functions, Earth Planets Space, 56, this issue, 1273-1279, 2004a.

H. Sato (e-mail: satow@eri.u-tokyo.ac.jp), T. Iwasaki, Y. Ikeda, T. Takeda, N. Matsuta, T. Imai, E. Kurashimo, N. Hirata, S. Sakai, D. Elouai, T. Kawanaka, S. Kawasaki, S. Abe, T. Kozawa, T. Ikawa, Y. Arai, and N. Kato 